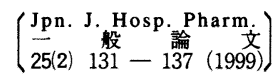

\title{
フロースルーセル法によるグリベンクラミド錠の薬物放出特性
}

岩田政則 $\uparrow^{1,2}$, 高橋由里 $\dagger^{1}$, 武内啓貴 $\dagger^{1}$, 川原恵美 $\uparrow^{1}$, 高山幸三 $\uparrow^{2}$, 城武昇一 $\dagger^{1}$

横浜市立大学医学部附属病院薬凨部 $\dagger^{1}$

星薬科大学薬珮学教室 $\dagger^{2}$

\section{Dissolution Profiles of Glibenclamide Tablet Using Flow-Through-Cell Method}

\author{
MASANORI IWATA $\dagger^{1,2}$, YURI TAKAHASHI $\dagger^{1}$, HIROTAKA TAKEUCHI $\dagger^{1}$, \\ EMI KAWAHARA $\dagger^{1}$, KOZO TAKAYAMA $\dagger^{2}$ and SHOICHI SHIROTAKE $\dagger^{1}$ \\ Department of Pharmacy, Yokohama City University Hospital $\dagger^{1}$ \\ Department of Pharmaceutics, Hoshi University $\dagger^{2}$
}

$\left(\begin{array}{c}\text { Received September 10, } 1998 \\ \text { Accepted December 24, } 1998\end{array}\right)$

Operating conditions affecting the dissolution characteristics of glibenclamide were investigated with the flow-through-cell method (the third method of dissolution test in JP XIII). The partition coefficient of glibenclamide between octanol and phosphate buffer $(\mathrm{pH} 7.4)$ was observed to be 24.2, thus suggesting the lipophilic nature of glibenclamide. The flow indicator on the apparatus in the flow-through-cell method did not reflect the real flow rate of the dissolution media.

The dissolution- time curve (ADT) value increased in line with the decrease in the bead's diameter when the flow rate of the indicator was slow $(8 \mathrm{ml} / \mathrm{min})$. On the other hand, the ADT value was hardly affected by the bead's diameter when the flow rate was fast $(24 \mathrm{ml} / \mathrm{min})$, however, a wide deviation in the ADT values was seen during such conditions. The operating condition of flow rate and bead's diameter was optimized based on the response surface method. As a result, a flow rate of $14 \mathrm{ml} / \mathrm{min}$ and a bead diameter of $0.5 \mathrm{~mm}$ were estimated as the optimal conditions to obtain the largest ADT and the smallest deviation in the ADT. When using the flow-through-cell method, the operating condition should be optimized based on the nature of pharmaceuticals under test.

Key words — flow-through-cell method, glibenclamide, tablets, dissolution test, operating condition

\section{緒言}

従来，薬物溶出試験を行うにあたり，日本薬局

$\dagger^{1} \quad$ 横浜市金沢区福浦3-9;3-9，Fukuura，Kanazawaku, Yokohama, Kanagawa, 236-0004 Japan

$\dagger^{2}$ 品川区荏原2-4-41;2-4-41, Ebara, Shinagawa-ku, Tokyo, 142-8501 Japan
方溶出試験第 1 法（回転バスケット法）および第 2 法（パドル法）が汎用されてきた.しかし，こ れらは，易溶性薬物を含有する固形製浏の溶出試 験として有用なものであるが，難溶性薬物を含有 する製羭の試験法としては適していない.これ は, 試験液の最大使用可能容量が約 $1000 \mathrm{ml}$ であ ることから，薬物の放出が試験液に対する溶解度 
に依存することに起因する。この問題を解決する ために，器具の改良や添加剤などの報告が多くの 研究者によってなされてきた ${ }^{1-3)}$. 第十二改正日本 薬局方（日局）第一追補より，新たに加わった溶 出試験第 3 法 (フロースルーセル法 $)^{4,5)}$ は, 試験 液を限りなく供給できることから，難溶性薬物含 有製剤の溶出性評価に有利であるとされる。しか し，現薬局方では適用となる製剈はなく，わが国 において使用経験が少ないのが現状である.

グリベンクラミド(6) は, 経口糖尿病用薬として 汎用される薬物であるが，難溶性であることや錠 剤として長期にわたり投与され, 薬物の吸収・効 果に影響を与える薬物溶出性の把握が重要とされ る. 本研究では, 溶出試験としてのフロースルー セル法の有用性と市販のグリベンクラミド錠をモ デルとしたときの薬物溶出特性から, 試験の最適 条件について検討した。

\section{実 験 の 部}

\section{1. 試薬類}

主薬であるグリベンクラミドは, シグマ社製の ものを，また市販のグリベンクラミド錠としてダ オニール®錠（日本へキストルセル社） $2.5 \mathrm{mg}$ を 使用した。その他の試薬類は, 特級品を使用し
た.

2. グリベンクラミドの特性

ネスラー管に日局 $\mathrm{pH} 7.4$ リン酸緩衝液 $(100 \mathrm{ml})$ と過量のグリベンクラミドを入れ， $37 \pm 0.5^{\circ} \mathrm{C} て ゙$ 48時間にわたり擋拌した後上澄み液を採取して $1500 \mathrm{rpm}$ で 5 分間遠心分離した。ささに，上澄み 液をメンブランフィルター $(0.22 \mu \mathrm{m})$ でろ過し て得たものを試料とした.試料中のグリベンクラ ミド量は,島津社製 UV2200を用いて228nmにお ける吸光度を測定した後, 検量線法により算出し た. 測定にあたり, 試料数は 5 個とした.

グリベンクラミド原末の油水分配率を求めるた めに，水相にグリベンクラミドを溶解した日局 pH7.4リン酸緩衝液と有機相にオクタノールを選

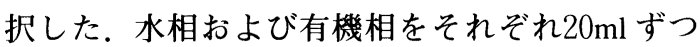
とり, $37.0 \pm 0.5^{\circ} \mathrm{C}$ 恒温槽で 24 時間振とうし た.オクタノールはあらかじめ水相を飽和させた ものを使用した。試験開始時および試験終了後の 水相中のグリベンクラミド濃度を前述の方法に従 い測定して，みかけの油水分配係数を求めた。測 定にあたり, 試料数は 3 個として平均值を求め た。

\section{3. 溶出試験}

1）日局第 3 法（フロースルーセル法）

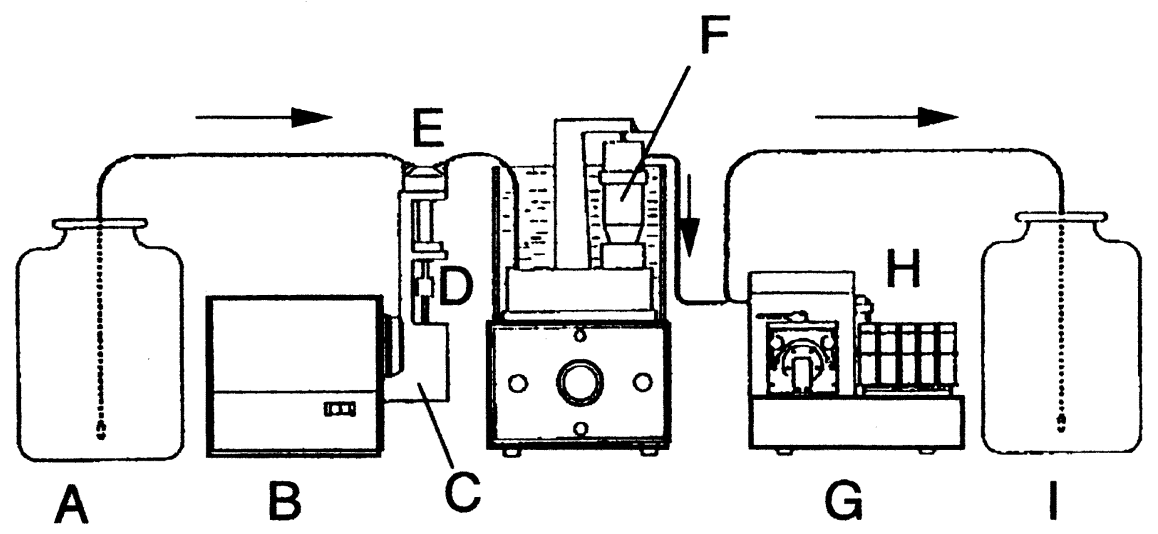

Fig. 1. System of Flow- Through- Cell Method

A ; Test fluid, B ; Piston pump, C ; Stroke change device (dial),

D ; Coupling, E ; Cylinder, F ; Cell, G ; Auto sampler, H ; Sample tube,

I ; Drainage 
試験装置の概念図を Fig. 1 に示す. 溶出試験シ ステムは, 富山産業社製溶出試験器 DISSOTEST100を使用して，セル部には, DISSOTEST CE1, ポンプ部はSOTAX CY1-50（SOTAX社, ス イス), サンプラー部はミニサンプラーワン (OTAX 社, スイス), 恒温槽は恒温槽マグスター バス (富山産業社), セル部は標準セル（直径12 $\mathrm{mm})$, ビーズ重量は直径 $1 \mathrm{~mm}$ のビーズをセルの 円錐部に設置したときの重量である $7.10 \mathrm{~g}$ とし た.

(1) ピストンポンプの特性

本システムで使用したピストンポンプについて 評価した.ダイヤル表示流速值を $5-50 \mathrm{ml} / \mathrm{min}$

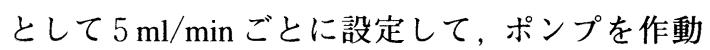
させた。試験開始30分後の液量を測定して, 実際 の流速を算出した.また，低流速域である $10,15,20$ $\mathrm{ml} / \mathrm{min}$ (表示流速值) において液量が $50 \mathrm{ml}, 100$ $\mathrm{ml}, 150 \mathrm{ml}$ および $200 \mathrm{ml}$ に達するまでの時間を測 定した. 測定は 3 回行い, 平均値を求めた.

(2) 薬物溶出に与えるビーズ径および流速の影 響

セル内に添加するガラスビーズの直径を 0.4 ,

2.0，4.0mm および表示流速を $8 ， 16 ， 24 \mathrm{ml} / \mathrm{min}$ を同時に変化させた複合 2 次中心球形実験計画》

（Table 1）を作成した。前述の方法に従い,グリ ベンクラミド錠の溶出試験を実施した。測定は 5 回行い, その平均值を求めた。

2 ）溶出されたグリベンクラミド濃度の測定
経時的に得られた試験液中のグリベンクラミド 濃度を前述の方法（UV 法）により測定し, 溶出 量を算出した。

\section{4. 数値計算}

各種パラメータの算出は, PC-9801FA（日本電 気社）を用いて, 山岡ら采のプログラムを利用し て行った.

\section{結果および考察}

\section{1. グリベンクラミドの特性}

グリベンクラミドの $\mathrm{pH} 7.4$ リン酸緩衝液に対す る飽和溶解度は, $5.13 \pm 0.31 \mu \mathrm{g} / \mathrm{ml}$ であった.し たがって, 本試験液 $900 \mathrm{ml}$ を用いて日局溶出試験 第 1 法, 第 2 法を行ったときのグリベンクラミド の溶解量は $4.88 \mathrm{mg}$ であることが推察される.ま た, pH7.4リン酸緩衝液を水相, オクタノールを 有機相としたときのみかけの油/水分配係数は, $24.2 \pm 4.8$ であった. 以上の結果より, グリベン クラミドが水に難溶性であること, 一般に溶解速 度が固体の溶解度の影響を受けること ${ }^{9)}$ などか ら, 薬物の試験液への溶解速度への影響が予想さ れた。

\section{2. 溶出試験}

1) ピストンポンプの特性

フロースルーセル法におけるポンプ流速ダイア ル值とポンプ運転開始30分後における排出液量よ り算出した流速の実測值の関係を, Fig. 2 に示 す.また, 低流速域において排出液量が $200 \mathrm{ml} に$

Table 1. Experimental Design and Actual Values of Two Facters (X1, X2)

\begin{tabular}{ccllc}
\hline Condition & \multicolumn{2}{c}{ X1 (bead diameter, mm) } & \multicolumn{2}{c}{ X2 (flow rate, $\mathrm{ml} / \mathrm{min}$ ) } \\
\hline A & $-\sqrt{2}$ & $(0.4)$ & $-\sqrt{2}$ & $(8)$ \\
B & -0.157 & $(2.0)$ & $-\sqrt{2}$ & $(8)$ \\
C & $\sqrt{2}$ & $(4.0)$ & $-\sqrt{2}$ & $(8)$ \\
D & $-\sqrt{2}$ & $(0.4)$ & 0 & $(16)$ \\
E & -0.157 & $(2.0)$ & 0 & $(16)$ \\
F & $\sqrt{2}$ & $(4.0)$ & 0 & $(16)$ \\
G & $-\sqrt{2}$ & $(0.4)$ & $\sqrt{2}$ & $(24)$ \\
H & -0.157 & $(2.0)$ & $\sqrt{2}$ & $(24)$ \\
I & $\sqrt{2}$ & $(4.0)$ & $\sqrt{2}$ & $(24)$ \\
\hline
\end{tabular}




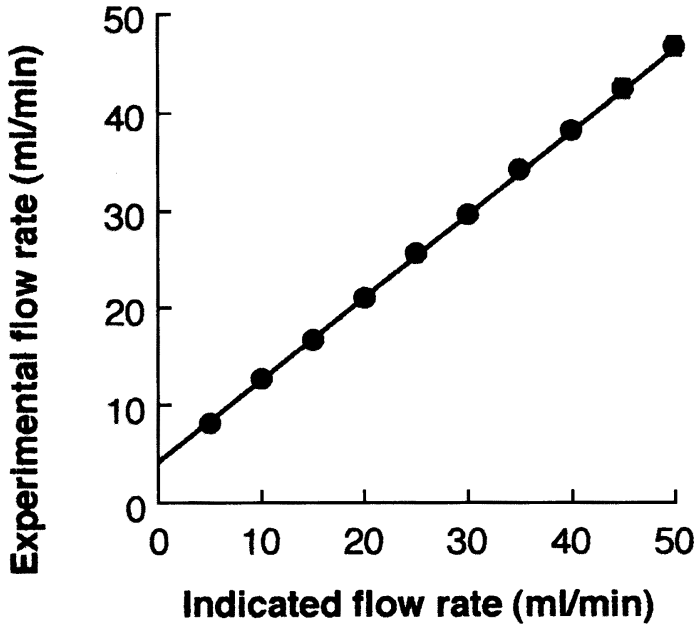

Fig. 2. Relationship between Scale of Dial (X) and Experimental Flow Rate (ml/ $\min )$

$$
\mathrm{Y}=4.3433+0.83890 \cdot \mathrm{X}\left(\mathrm{r}^{2}=1.000\right)
$$

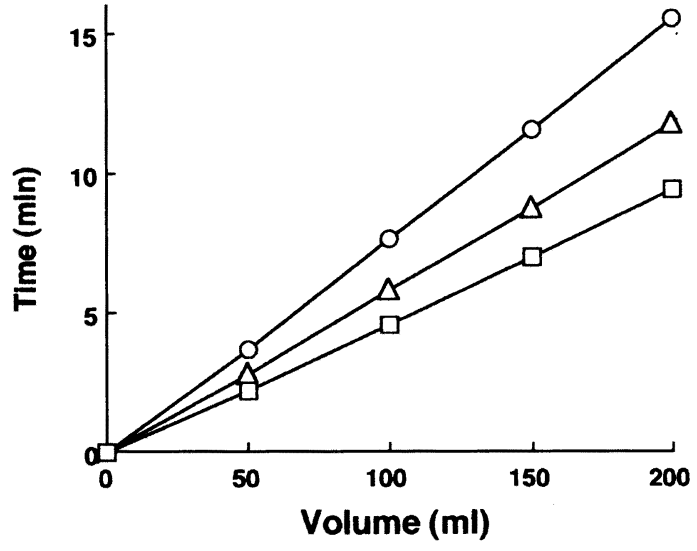

Fig. 3. Flow Profiles of Test Fluid on Device for Flow-Through-Cell Method ( JP X III)

$\bigcirc ; 10 \mathrm{ml} / \mathrm{min}, \triangle ; 15 \mathrm{ml} / \mathrm{min}$, ; $20 \mathrm{ml} / \mathrm{min}$
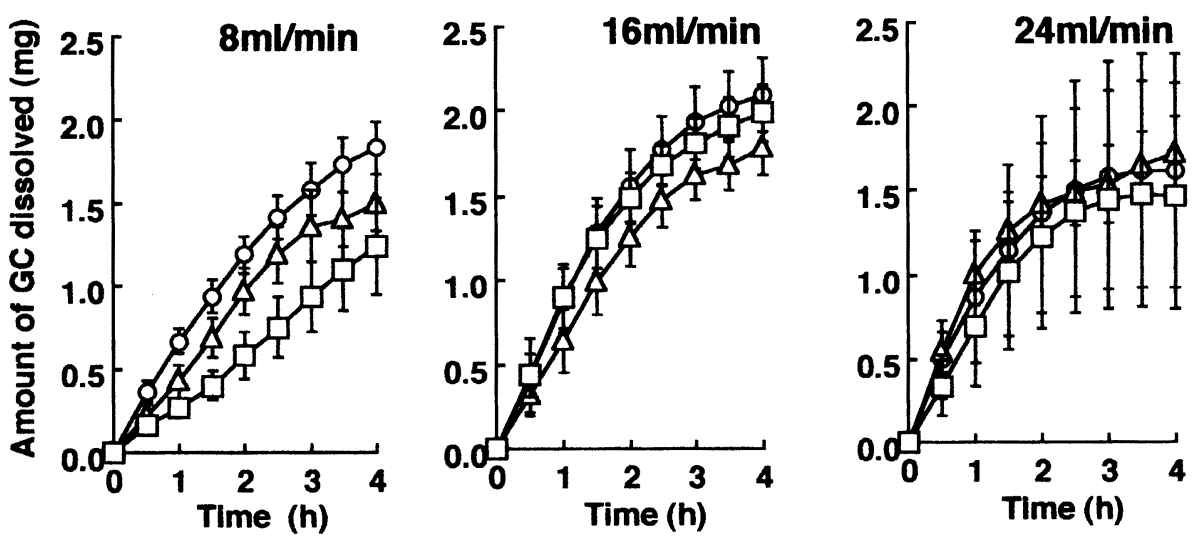

Fig. 4. Effect of Beads Diameter to Dissolution on Various Flow Rate Using Flow-Through-Cell Method

$\bigcirc ; 0.4 \mathrm{~mm}, \triangle ; 2.0 \mathrm{~mm}, \square ; 4.0 \mathrm{~mm}$

なるまでの排出液量の変化を Fig. 3 に示す．表 示流速值 $(\mathrm{X})$ で実測值 $(\mathrm{Y})$ を一次回帰式で予測 したところ, $\mathrm{Y}=4.34+0.839 \cdot \mathrm{X}\left(\mathrm{r}^{2}=1.000\right)$ で あった. 式の傾きが1.0でなかったこと，Y 切片 が原点を通過しなかったことにより，ダイアルの 表示值が必ずしも実測值を表さずにあくまで参考 值として取り扱う必要がある。しかし，本試験で は換算の煩雑性を考慮してダイヤル表示值をみか
けの流速値としてこれを使用して議論を行った.

一方，みかけの流速値（ダイヤル表示流速値）を低 速としたときの経時的な排出挙動は，いずれの条 件においても直線性を示したことから，試験中の 排出量のばらつきは少ないといえる.

2 ) 溶出試験

フロースルーセル法において，流速およびガラ スビーズ径を変化させたときの薬物溶出挙動を 

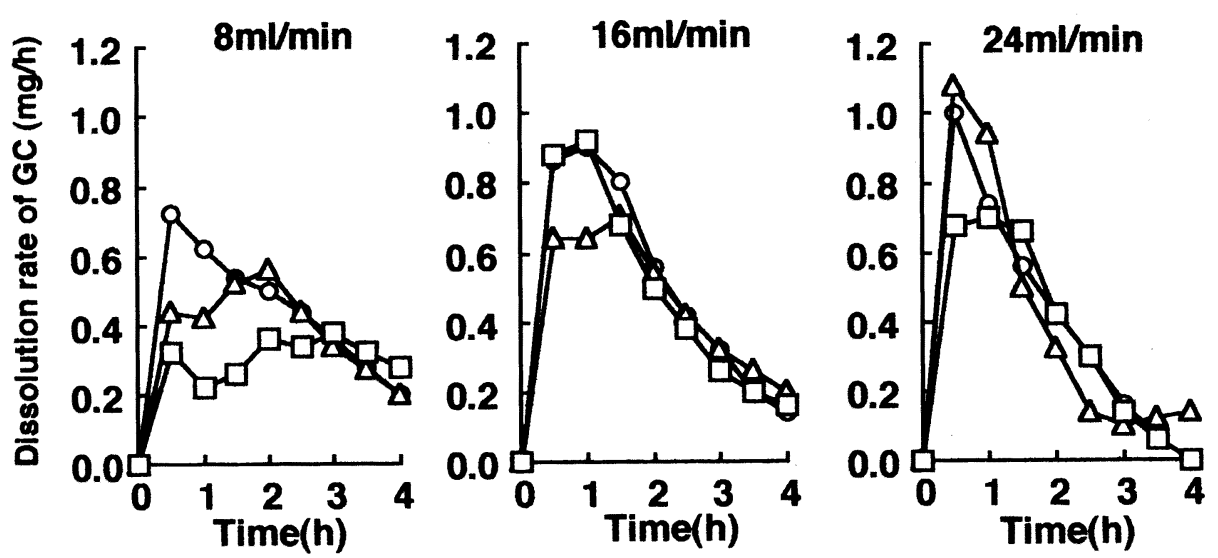

Fig. 5. Effect of Beads Diameter to Dissolution Rate on Various Flow Rate Using Flow-Though-Cell Method $\bigcirc ; 0.4 \mathrm{~mm}, \triangle ; 2.0 \mathrm{~mm}, \square ; 4.0 \mathrm{~mm}$

Table 2. Experimental Design and Observed Values in Seven Responsive Variables

\begin{tabular}{cccccccr}
\hline Condition & $\begin{array}{c}\text { ADT } \\
(\mathrm{mg} \cdot \mathrm{h})\end{array}$ & $\begin{array}{c}\text { MDT } \\
(\mathrm{h})\end{array}$ & $\begin{array}{c}\text { C.V. (ADT) } \\
(\%)\end{array}$ & $\begin{array}{c}\text { C.V. (MDT) } \\
(\%)\end{array}$ & $\begin{array}{c}\text { T 16\% } \\
(\mathrm{h})\end{array}$ & $\begin{array}{c}\text { T 50\% } \\
(\mathrm{h})\end{array}$ & $\begin{array}{c}\text { T 84\% } \\
(\mathrm{h})\end{array}$ \\
\hline A & 1.69 & 1.60 & 9.5 & 6.3 & 0.61 & 1.56 & 4.31 \\
B & 1.41 & 1.65 & 12.8 & 7.3 & 0.85 & 2.92 & 10.13 \\
C & 1.13 & 2.01 & 23.9 & 6.5 & 1.29 & 5.21 & 21.48 \\
D & 1.96 & 1.43 & 9.2 & 7.0 & 0.54 & 1.47 & 4.04 \\
E & 1.65 & 1.51 & 8.5 & 9.3 & 0.64 & 2.04 & 6.58 \\
F & 1.84 & 1.39 & 8.9 & 7.9 & 0.44 & 1.53 & 4.81 \\
G & 1.49 & 1.17 & 12.1 & 7.7 & 0.39 & 1.94 & 9.95 \\
H & 1.57 & 1.18 & 12.1 & 13.6 & 0.32 & 1.72 & 10.64 \\
I & 1.50 & 1.28 & 13.3 & 14.8 & 0.56 & 2.15 & 8.35 \\
\hline
\end{tabular}

Fig. 4 に，また薬物放出速度の変化を Fig. 5 に 示す. 流速が $8 \mathrm{ml} / \mathrm{min}$ のとき薬物放出量はビー ズ径が小さいほど大きな值を示し, 溶出速度の変 化は緩やかであった。

流速が $16 \mathrm{ml} / \mathrm{min}$ では，ビーズ径との間に大き な差は見られずほぼ同様な放出挙動を示した。一 方, 流速が $24 \mathrm{ml} / \mathrm{min}$ と速い条件ではビーズ径の 影響は見られなかったが，ばらつきは大きくなり 一定の值を示さなかった. 試験開始初期の薬物溶 出速度を比較したとき，いずれのビーズ径におけ る $24 \mathrm{ml} / \mathrm{min}$ の30分值も, $8 \mathrm{ml} / \mathrm{min}$ の約 2 倍とな り時間の経過とともに急激に低下した。

各試験条件における薬物溶出パラメータの
ADT ( 4 時間), モーメント解析で得られた平均 溶出時間（MDT）とその変動係数および Wagner の対数正規分布モデル10)より得られた $16 \%$ 溶出 時間 (T16\%)，50\%溶出時間 (T50\%) および84\% 溶出時間 $(\mathrm{T} 84 \%)$ を Table 2 に示す. ADTお よびMDTをみると, 条件 $\mathrm{C}(4.0 \mathrm{~mm}, 8 \mathrm{~mm} / \mathrm{min})$ すなわち本実験領域において大きいビーズと遅い 流速で薬物溶出量が小さく, 緩やかに溶出した. また, 条件 Cでは ADT の変動係数が $23.9 \%$ と大 きく溶出性に関してばらつきが顕著であった. ADT の值が大きい条件では, D, F, Eの順で

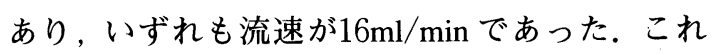
より, 本実験領域内に, 薬物溶出性に関して最適 
な流速条件の存在が推察された.

各試験条件で得られた ADT およびその変動係 数を従属変数（Y1，Y 2）, ビーズ径および流速 を説明変数 $(\mathrm{X} 1, \mathrm{X} 2)$ として 2 次多項式を基 本とした因子選択型重回帰分析を実施してその予 測を試みた。

得られた最適予測式と三次元図を Table 3， Fig. 6 に示す. その結果，それぞれの特性值（Y $1, \mathrm{Y} 2$ ）は，Xl扎よびX2の影響を受けるこ
とが示された。ADT（Y1）の最適予測式の相関

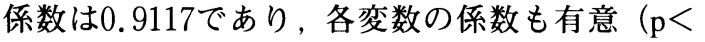
0.05）であった。一方, 変動係数 (Y 2$)$ の最適 予測式の相関係数が 0.8600 であったことからその 予測性はやや低下するものといえる，各最適予測 式の信頼性を確認するために，ビーズ径を 1.0 $\mathrm{mm}$, みかけの流速を $8 \mathrm{ml} / \mathrm{min}, 16 \mathrm{ml} / \mathrm{min}, 24 \mathrm{ml} /$ $\min$ としてグリベンクラミド錠の溶出試験を実施 した. ADT およびその変動係数に関して, 予測

Table 3. Optimum Regression Equation for ADT and C.V. (ADT) Determined by Multiple Regression Analysis

\begin{tabular}{lrrrrrrr}
\hline & $\mathrm{X} 1$ & $\mathrm{X} 2$ & $\mathrm{X} 12$ & $\mathrm{X} 22$ & $\mathrm{X} 1 \mathrm{X} 2$ & Const. & $\mathrm{R}$ \\
\hline ADT & -0.0771 & - & - & -0.1759 & 0.0686 & 1.8126 & 0.9117 \\
C.V. (ADT) & 1.7547 & - & - & 2.6591 & -1.6302 & 8.7252 & 0.8600 \\
\hline
\end{tabular}

ADT ; Area under the dissolution time curve from 0 to 4 hours

C.V. (ADT) ; Coefficient of variation of obtained ADT

Table 4. Comparisons between Predicted and Experimental Values under the Condition by the Flow- Though- Cell Method

\begin{tabular}{cccccc}
\hline \multirow{2}{*}{$\begin{array}{c}\text { Condition } \\
\text { Bead/Flow rate }\end{array}$} & \multicolumn{2}{c}{ ADT } & & \multicolumn{2}{c}{ C.V. (ADT) } \\
\cline { 2 - 3 } \cline { 5 - 6 } & \multicolumn{2}{c}{ Predicted Experimental } & & Predicted Experimental \\
\hline $1.0 \mathrm{~mm} / 8 \mathrm{ml} / \mathrm{min}$ & 1.82 & $1.87 \pm 0.24 *$ & & 10.2 & 12.8 \\
$1.0 \mathrm{~mm} / 16 \mathrm{ml} / \mathrm{min}$ & 1.89 & $1.96 \pm 0.35$ & & 17.1 & 17.9 \\
$1.0 \mathrm{~mm} / 24 \mathrm{ml} / \mathrm{min}$ & 1.44 & $1.45 \pm 0.22$ & & 14.6 & 15.2 \\
\hline
\end{tabular}

$*$; mean \pm S.D. $(\mathrm{N}=6)$.
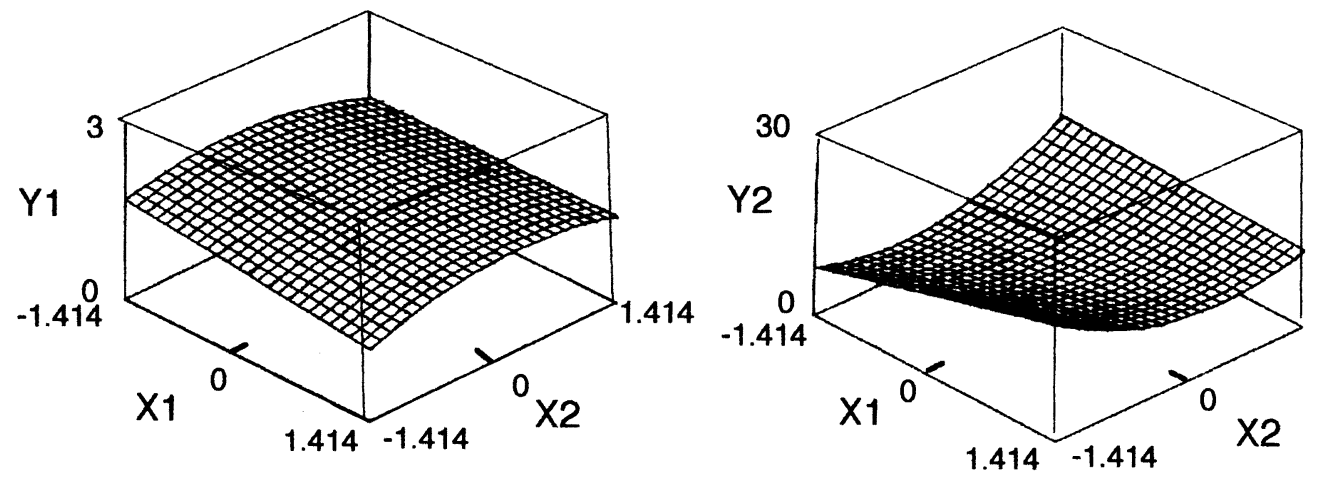

1.414

Fig. 6. Three Dimensional Diagram of Optimum Regression Equation for ADT and C.V of ADT $\mathrm{Y} 1$; ADT, Y2 ; C.V. of ADT, X1 ; bead diameter, X2 ; flow rate 
Table 5. Optimum Condition on Dissolution Test of GC Tablet by the FlowThrough-Cell Method

\begin{tabular}{lll}
\hline & Coded point & Actual value \\
\hline $\mathrm{X} 1$ & -1.390 & $0.46 \mathrm{~mm}$ \\
$\mathrm{X} 2$ & -0.262 & $14 \mathrm{ml} / \mathrm{min}$ \\
\hline
\end{tabular}

值および実測值を Table 4 に示す. 本結果より， 予測值と実測值は同様な值を示したことから，本 手法の有用性が確認された.

ADT（Y 1 ）および変動係数（Y 2 ）の最適予 測式を用いて本実験域内におけるビーズ径と流速

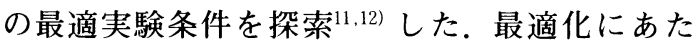
り, 探索条件を ADT が最大值, 変動係数が最小 值を理想値となるように設定した。得られた最適 実験条件を Table 5 に示す．以上の結果より， グリベンクラミド錠の溶出試験にあたり，ビーズ 径は約 $0.5 \mathrm{~mm}$, 流速は約 $14 \mathrm{ml} / \mathrm{min}$ で行うことが 望ましいといえる。

フロースルーセル法は, グリベンクラミド錠の ような難溶性薬物を含有する製剤の溶出試験に有 用な方法であること，その試験に際して ADT が 大きく，ばらつきが小さい最適条件が存在するこ とが明らかとなった，日本薬局方では，ガラス球 (ビーズ径) は $1 \mathrm{~mm}$ で, 定められた流量（流速）
で行うことが規定されている。しかし，医薬品各 条での対象となる医薬品・製郕がないことから， 製剤ごとに最適条件を得た上で溶出試験を実施す ベきであると考える.

\section{引用文献}

1) Y. Machida, T. Tokumura, S. Komuro, Y. Tsushima, K. Tatsuishi, M. Kayano, T. Nagai, Chem. Pharm. Bull., 34, 2637-2641 (1986).

2) T. Tokumura, Y. Tsushima, K. Tatsuishi, M. Kayano, Y. Machida, T. Nagai, YAKUZAIGAKU, 47, 100-104 (1987).

3) J.T. Carstensen 編, 永井恒司訳, “医薬品の溶 出”, 地人書館, 東京, 1978, pp. 66-84.

4) 日本薬局方解説書編集委員会編, “第十三改正日 本薬局方解説書”, 廣川書店, 東京, 1998, pp.182185.

5）日本公定書協会編，“日本薬局方技術情報1996, ” 薬業時報社, 東京, 1996, pp.182-185.

6）角井かず代，医薬ジャーナル，31，1097-1102 (1995).

7) 朝尾正, 安藤貞一, 楠正, 中村恒夫, “最新実験 計画法”, 日科技連, 東京, 1973, pp.331-341.

8）山岡清, “マイコンによる薬物体内動態解析法”, 南江堂, 東京, 1984, pp.145-184.

9) 南原利夫監修, “物理薬剤学”, ミクス, 東京, 1998, pp.43-49.

10) J.Wagner, J. Pharm. Sci., 58, 1253-1257 (1969).

11) K.Takayama, H.Obata, T.Nagai, Int.J.Pharm., 61, 225-234 (1990).

12) K,Takayama, H.Okabe, Y.Obata, T.Nagai, Int. J. Pharm., 74, 115-126 (1990). 